\title{
Article \\ Clearance of Gram-Negative Bacterial Pathogens from the Ocular Surface by Predatory Bacteria
}

\author{
Eric G. Romanowski ${ }^{1}{ }^{\circledR}$, Shilpi Gupta ${ }^{2}$, Androulla Pericleous ${ }^{2}$, Daniel E. Kadouri ${ }^{2}{ }^{\circledR}$ and Robert M. Q. Shanks ${ }^{1, *}$ \\ 1 Charles T. Campbell Eye Microbiology Laboratory, Department of Ophthalmology, The Eye and Ear Institute, \\ University of Pittsburgh School of Medicine, 203 Lothrop Street, Room 1020, Pittsburgh, PA 15213, USA; \\ romanowskieg@upmc.edu \\ 2 Department of Oral Biology, Rutgers School of Dental Medicine, 110 Bergen St, Newark, NJ 07103, USA; \\ sgupta1109@gmail.com (S.G.); androulla830@gmail.com (A.P.); kadourde@sdm.rutgers.edu (D.E.K.) \\ * Correspondence: shanksrm@upmc.edu; Tel.: +1-(412)-647-3537
}

\section{check for}

updates

Citation: Romanowski, E.G.; Gupta, S.; Pericleous, A.; Kadouri, D.E.; Shanks, R.M.Q. Clearance of Gram-Negative Bacterial Pathogens from the Ocular Surface by Predatory Bacteria. Antibiotics 2021, 10, 810. https://doi.org/10.3390/antibiotics 10070810

Academic Editors: Mark Willcox,

Fiona Stapleton, Debarun Dutta and Ilias Karaiskos

Received: 21 May 2021

Accepted: 1 July 2021

Published: 3 July 2021

Publisher's Note: MDPI stays neutral with regard to jurisdictional claims in published maps and institutional affiliations.

Copyright: (c) 2021 by the authors. Licensee MDPI, Basel, Switzerland. This article is an open access article distributed under the terms and conditions of the Creative Commons Attribution (CC BY) license (https:// creativecommons.org/licenses/by/ $4.0 /)$.

\begin{abstract}
It was previously demonstrated that predatory bacteria are able to efficiently eliminate Gram-negative pathogens including antibiotic-resistant and biofilm-associated bacteria. In this proof-of-concept study we evaluated whether two species of predatory bacteria, Bdellovibrio bacteriovorus and Micavibrio aeruginosavorus, were able to alter the survival of Gram-negative pathogens on the ocular surface. Clinical keratitis isolates of Pseudomonas aeruginosa (strain PAC) and Serratia marcescens (strain K904) were applied to the ocular surface of NZW rabbits followed by application of predatory bacteria. At time intervals, surviving pathogenic bacteria were enumerated. In addition, B. bacteriovorus and S. marcescens were applied to porcine organ culture corneas under contact lenses, and the ocular surface was examined by scanning electron microscopy. The ocular surface epithelial layer of porcine corneas exposed to $S$. marcescens, but not B. bacteriovorus was damaged. Using this model, neither pathogen could survive on the rabbit ocular surface for longer than $24 \mathrm{~h}$. $M$. aeruginosavorus correlated with a more rapid clearance of $P$. aeruginosa but not $S$. marcescens from rabbit eyes. This study supports previous evidence that predatory bacteria are well tolerated by the cornea, but suggest that predatory bacteria do not considerably change the ability of the ocular surface to clear the tested Gram-negative bacterial pathogens from the ocular surface.
\end{abstract}

Keywords: ocular infection; predatory bacteria; Bdellovibrio; Micavibrio; Pseudomonas aeruginosa; Serratia marcescens; conjunctivitis; keratitis

\section{Introduction}

Predatory bacteria including Bdellovibrio bacteriovorus and Micavibrio aeruginosavorus are Gram-negative bacteria that prey upon other Gram-negative bacteria [1,2]. These species are able to prey on a wide range of antibiotic-resistant bacteria including many human pathogens [3,4] such as ocular isolates of Pseudomonas aeruginosa and Serratia marcescens [4]. B. bacteriovorus has a broad host-range by which it invades the bacterial cell and replicates in the bacterial periplasm, whereas $M$. aeruginosavorus exhibits a narrower host-range and acts as an epibiotic predator as it attaches to the outside of prey bacteria [5]. These predators were shown to be highly effective against bacteria in biofilms, which are notoriously recalcitrant to traditional antibiotic therapy [6-9].

We previously postulated that predatory bacteria could be used as a topical treatment for bacterial infection of the eye and demonstrated that predatory bacteria are not toxic to human ocular surface cell lines and well tolerated on the ocular surface of rabbits $[4,10]$. Other groups have found similar tolerability of predatory bacteria on leporine and bovine ocular surfaces [11,12]. Furthermore, intravenous and intranasal inoculation of Micavibrio and Bdellovibrio species, even at high numbers, caused no morbidity or mortality in mice, although they did mildly increase production of proinflammatory cytokines IL-6, TNFalpha, and chemokine CXCL-1 [13], and numerous mammalian cell lines were unperturbed 
by Bdellovibrio strains $[4,14,15]$. Together, these data suggest that Bdellovibrio and Micavibrio species can be safely used as an experimental therapeutic. Additionally, in vivo studies had reviled that predatory bacteria have potential as "living antimicrobials" for control of pathogens. B. bacteriovorus have shown efficacy in limiting Klebsiella pneumoniae and Yersinia pestis proliferation in airway and systemic rodent infection models $[16,17]$. Similarly, they were able to prey upon Shigella flexneri in the hindbrain of zebrafish, promoting the survival of the zebrafish larvae [18].

Ocular infections caused by Gram-negative bacteria, such as keratitis, are associated with contact lens use and can lead to a loss of ocular acuity [19-21]. Leading causes of these infections include Pseudomonas aeruginosa and Serratia marcescens [22-24]. Antibiotic resistance has been noted among keratitis isolates and is correlated with worse clinical outcomes [24-29]. Due to the need for new approaches to treat resistant microbial infections, we evaluated the ability of B. bacteriovorus and M. aeruginosavorus to promote the clearance of keratitis isolates of $S$. marcescens and fluoroquinolone-resistant $P$. aeruginosa and from the ocular surface using a rabbit ocular surface occupancy model.

\section{Results}

2.1. Scanning Electron Microscopy Visualization of B. bacteriovorus 109J with Porcine Corneas Ex Vivo

As a first step in the study we visualized the interaction of predatory bacteria and the cornea in order to determine whether predatory bacteria could adhere to the corneal surface and whether there was any clear impact of this interaction using B. bacteriovorus 109J as a representative strain of predatory bacteria. Although a previous study demonstrated the absence of a clinical inflammatory response by rabbits, it did not evaluate the ocular surface at a microscopic level. Figure 1 depicts ex vivo porcine corneas from an organ culture model where B. bacteriovorus strain 109J was in contact with the ocular surface under a contact lens for $3 \mathrm{~h}$. The predatory bacteria could adhere to the ocular surface, but failed to produce any clear epithelial damage similar to the mock treated (no bacteria) samples. By comparison, when using a sample Gram-negative pathogen, S. marcescens strain K904, under the same experimental conditions, adherent bacteria were present and were associated with erosion-like areas.

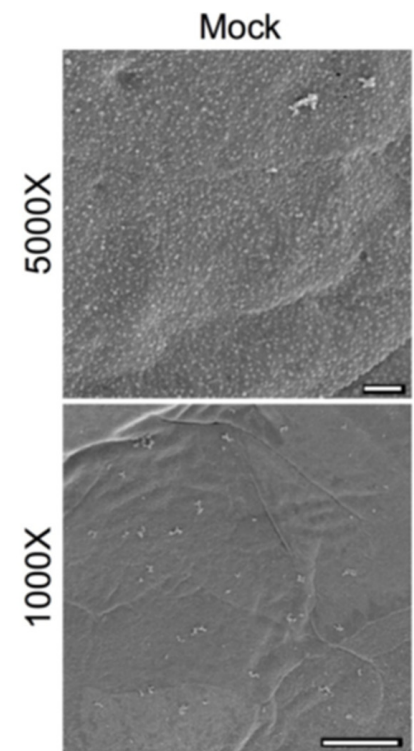

Mock

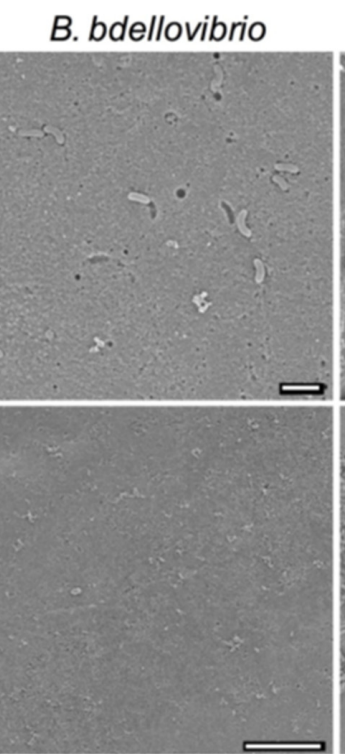

B. bdellovibrio
S. marcescens

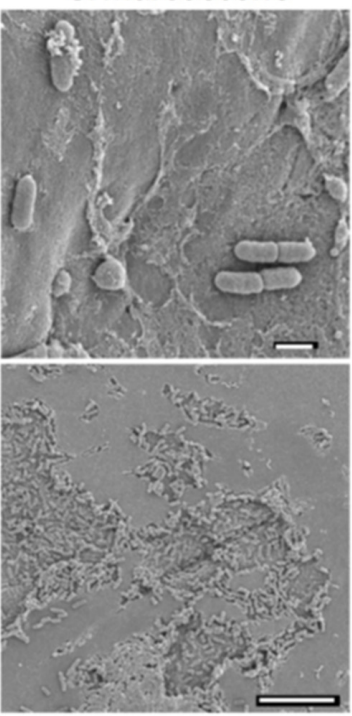

S. marcescens

Figure 1. SEM micrographs of porcine corneal surfaces exposed to bacteria for $3 \mathrm{~h}$ ex vivo. Representative images are shown. Top row bars, $1 \mu \mathrm{m}$. Bottom row bars, $10 \mu \mathrm{m}$. Both B. Bdellovibrio strain 109J and S. marcescens strain K904 could adhere to the corneal surface, but S. marcescens was associated with damage to the epithelium. 
2.2. Clearance of Fluoroquinolone Resistant P. aeruginosa But Not S. marcescens from Rabbit Ocular Surfaces Was Facilitated by Instillation of Predatory Bacteria

The survival of a fluoroquinolone-resistant keratitis isolate of P. aeruginosa (strain PAC) was evaluated on the ocular surface of NZW rabbits. PAC was previously shown to be susceptible to the predatory bacteria used in this study in vitro [4]. It was shown that PAC was reduced $2.13 \log _{10}$ CFU by B. bacteriovorus 109J, $3.91 \log _{10}$ CFU by B. bacteriovorus HD100 and $2.98 \log _{10}$ CFU by $M$. aeruginosavorus ARL-13. Predatory bacteria or saline was applied topically at 1,3 , and 5 h post-instillation of $P$. aeruginosa, and bacteria were enumerated at $0.5,2$, and 4 , and $24 \mathrm{~h}$ (Figure $2 \mathrm{~A}$ ). No growth was measured from the samples taken at $24 \mathrm{~h}$.
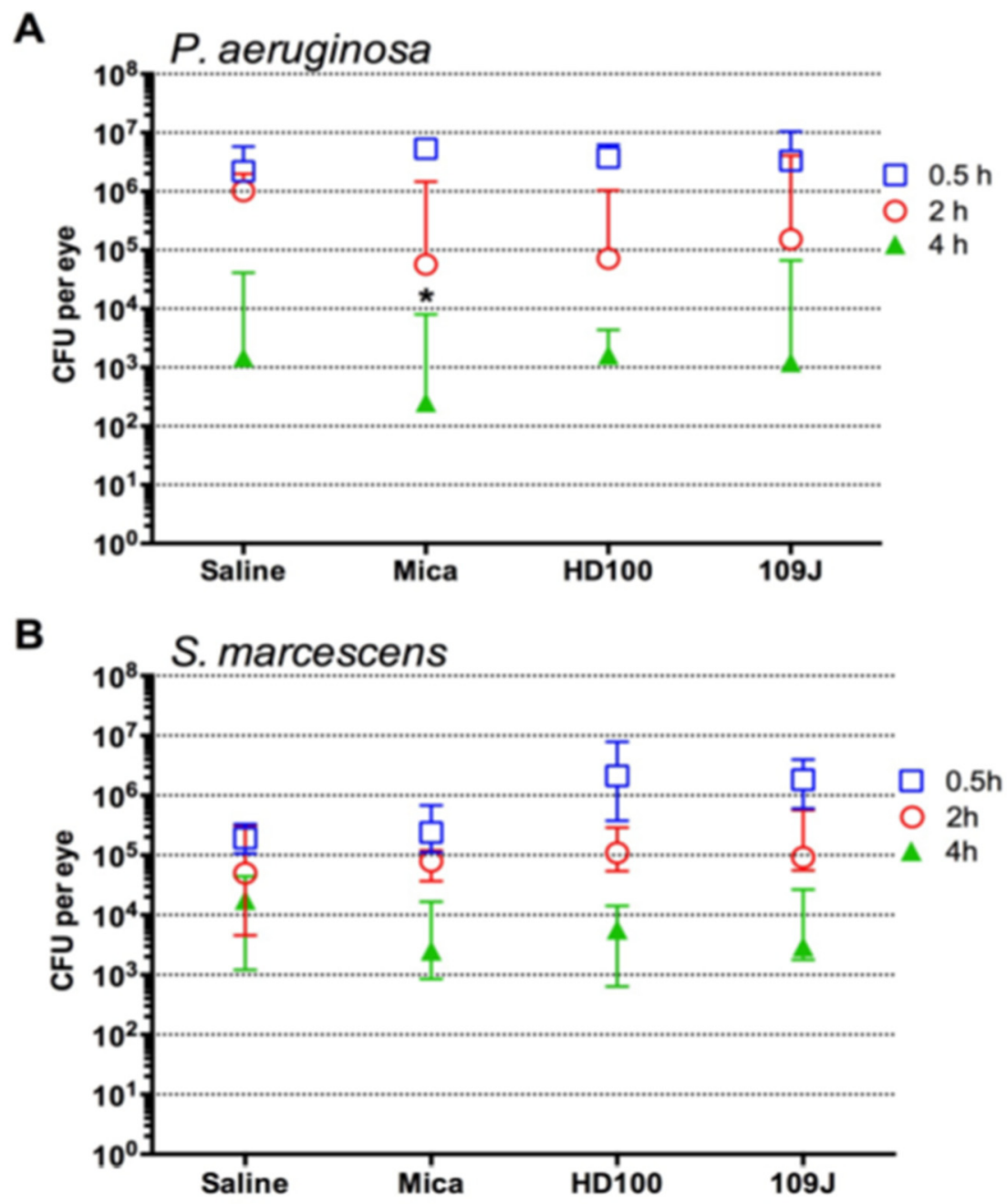

Figure 2. Predatory bacteria impact the ocular surface survival of P. aeruginosa and S. marcescens. $(\mathbf{A}, \mathbf{B})$. Medians and interquartile ranges of bacterial CFU from ocular surface of New Zealand white rabbits, (A). P. aeruginosa, $n=12$ eyes per group. (B). S. marcescens, $n=8$ eyes per group. Asterisks indicate significant differences from saline at the same time point $(p<0.05)$ as determined by Mann-Whitney test.

In the saline group, median PAC levels remained steady at over $10^{6} \mathrm{CFU}$ for the first $2 \mathrm{~h}$ then dropped down to just under $1500 \mathrm{CFU}$ per swab at $4 \mathrm{~h}$. Notably between hour 0 and 2 there was no clear reduction in PAC in the saline treated eyes, whereas the predatory bacteria treated eyes had a reduction in the number of PAC bacteria. PAC CFU dropped 2.0, 1.7, and $1.3 \log _{10}$ for B. bacteriovorus109J, Micavibrio (Mica), and B. bacteriovorus HD100, respectively, between 2 and $4 \mathrm{~h}$. PAC CFU from the Mica treatment group at $4 \mathrm{~h}$ post- 
inoculation (254 CFU) was significantly different than the saline treatment group (1483 CFU), (Mann-Whitney $p<0.05)$.

The same approach was performed with $S$. marcescens contact lens associated keratitis isolate K904, which is also susceptible to predatory bacteria in vitro [30]. Garcia et al. showed that B. bacteriovorus 109J reduced S. marcescens K904 CFU by $4.1 \log _{10}$ CFU but only $0.3 \log _{10}$ CFU by M. aeruginosavorus ARL-13 [30]. Here, we evaluated S. marcescens strain K904 predation by B. bacteriovorus $\mathrm{HD} 100$ in vitro and measured a $3.92 \pm 0.17 \log _{10}$ CFU reduction compared to an increase of $0.17 \pm 0.12 \mathrm{CFU}$ change in the control samples without predatory bacteria $(n=3)$. S. marcescens CFU were similar at 0 and $2 \mathrm{~h}$ but were reduced at $4 \mathrm{~h}$ on the rabbit ocular surface (Figure 2B) compared with the saline control. Predatory bacteria did not significantly impact the survival of $S$. marcescens on the ocular surface.

\section{Discussion}

This study indicated that the predatory bacterium B. bacteriovorus strain 109J was not damaging to live corneas when tested in an organ culture model, which is consistent with previous studies indicating that predatory bacteria are well tolerated by tissue culture cell lines and mammals $[10,12,14-16,18]$. By contrast a representative ocular surface pathogen, S. marcescens caused clear damage to the corneal epithelia. This may be due to the many cytotoxic enzymes, such as PrtS, SlpB, and SlpE metalloproteases, and the pore-forming toxin ShlA, previously shown to be cytotoxic to ocular surface cells [31-33].

Two previous studies have evaluated the ability of predatory bacteria to reduce bacterial counts on the ocular surface; one with Shigella flexneri was inconclusive with respect to predation as the $S$. flexneri numbers were reduced following application of either B. bacteriovorus or non-pathogenic Escherichia coli [11]. In another study, lyophilized B. bacteriovorus strain 109J was used in topical treatment of calf corneas that had been infected with pathogenic Moraxella bovis using an infectious bovine keratoconjunctivitis model [12]. Boileau and colleagues concluded that the treatment group did not differ from the control group in treatment of the ocular surface infection [12]. By contrast, B. bacteriovorus treatment has been effective in reducing pathogen numbers in rat lung and zebrafish larvae hindbrain infection models $[13,18]$ and reducing Salmonella numbers in the gut of chickens following oral dosing [34]. Therefore, it is clear that there are physiological limits to where predatory bacteria can be used as alternatives to antibiotics. The ocular surface is a notably hostile environment to bacteria and is considered paucibacterial with relatively few bacteria compared to other exposed mucosal surfaces [35]. Although DNA for Gram-negative bacteria have been isolated from the ocular surface following PCR amplification in several studies, it is not clear that they are constituents of the normal ocular microbiome, which is dominated by Gram-positive genera such as Corynebacterium and Staphylococcus that are resistant to the tested predatory bacteria [35-37]. Therefore, as was demonstrated for the rat gut microbiome [38], it is not expected that predatory bacteria would have a major effect on the ocular surface microbiome. Furthermore, B. bacteriovorus abundance has been positively correlated with a healthy gut microbiome and the absence of inflammatory disease in humans, suggesting a beneficial role for these organisms [39].

The act of swabbing or proparacaine topical anesthetic solution may have influenced the outcome of the study. Proparacaine has been shown to inhibit Staphylococcus aureus, but not $P$. aeruginosa growth in vitro [40]. However, a veterinary study demonstrated no significant effect of proparacaine on the number of bacteria isolated from ocular surface samples, suggesting that proparacaine did not impact this study [41]. Similarly, previous studies have demonstrated rapid clearance of P. aeruginosa on the ocular surface of rodents [42], suggesting that the rapid reduction of pathogen bacteria on the ocular surface was due to the innate immune system of the eye rather than due to swabbing the ocular surface.

There was a correlation of the presence of predatory bacteria with a reduction in P. aeruginosa CFU on the ocular surface at 2 and $4 \mathrm{~h}$ that only reached significance with $M$. aeruginosavorus. By contrast $S$. marcescens surface occupancy was not altered by the pres- 
ence of predatory bacteria. The in vitro reduction of S. marcescens K904 ( 4-log reduction) by B. bacteriovorus was higher than for P. aeruginosa PAC (2.1-3.9-log reduction); whereas M. aeruginosavorus reduced P. aeruginosa PAC ( $\sim-\log$ reduction) greater than $S$. marcescens K904 ( 0.3-log reduction) in vitro [4,30]. While it is clear that these pathogens were preyed upon in vitro, whether there was active predation on the ocular surface was not formally determined in this pilot study. Indeed, predatory bacteria may stimulate the immune system to promote clearance of $P$. aeruginosa. Consistent with this hypothesis, in a zebrafish infection study, predatory bacteria preyed upon S. flexneri in the hind brain, but full clearance of the pathogen required both the predatory bacteria and the immune system [18]. On the ocular surface, colonization of Corynebacterium species can promote resistance to Pseudomonas infections that is dependent upon an IL-17 signaling mechanism [43]. It is possible that the predatory bacteria are invoking a similar protective immune response in rabbits.

Together, these data suggest that predatory bacteria are not damaging to the corneal epithelium and can influence the occupancy of pathogens on the ocular surface, but that they are not an effective method of clearing pathogens beyond that of the natural host defense systems.

\section{Materials and Methods}

\subsection{Bacterial Strains and Culture}

Keratitis isolates of P. aeruginosa strain PAC [44] and S. marcescens strain K904 [45] were used in this study. The P. aeruginosa strain was determined to be resistant to fluoroquinolone antibiotics (ciprofloxacin, gatifloxacin, ofloxacin, levofloxacin, and moxifloxacin) in a College of American Pathologists (CAP) and Clinical Laboratory Improvement Amendments (CLIA) certified microbiology laboratory following Clinical and Laboratory Standards Institute (CLSI) guidelines [44,46]. Susceptibility was interpreted using the CLSI (Clinical \& Laboratory Standards Institute) serum standards and procedures for disk diffusion [46], and later determined using E-tests [47].

These bacteria were maintained in glycerol frozen stocks and were streaked to single colonies on TSA medium with 5\% red blood cells (Blood agar) (Remel, Lenexa, KS) before use as described below. Bacteria were also cultured with lysogeny broth (LB) and LB with agar [48]. The predatory bacteria used in the study were B. bacteriovorus 109J [49] B. bacteriovorus HD100 (ATCC 15356) [50], and M. aeruginosavorous strain ARL-13 [51]. Predator lysates (cocultures) were prepared as reported previously [14,16]. In brief, B. bacteriovorus and M. aeruginosavorus were incubated with E. coli strain WM3064 $\left(1 \times 10^{9} \mathrm{CFU} / \mathrm{mL}\right)$ at $30^{\circ} \mathrm{C}$ for 24 and $72 \mathrm{~h}$, respectively. The cleared lysates were filtered several times through a $0.45-\mu \mathrm{m}$ Millex ${ }^{\circledR}$-HV pore-size filter (Millipore, Billerica, MA, USA) in order to remove residual prey. Predators were washed and concentrated by sequential centrifugation cycles. The final predator pellets were re-suspended in Phosphate Buffered Saline (PBS) to reach final concentrations of $1 \times 10^{10} \mathrm{PFU} / \mathrm{mL}$ B. bacteriovorus and $1 \times 10^{9} \mathrm{PFU} / \mathrm{mL}$ M. aeruginosavorus.

\subsection{Scanning Electron Microscopy}

B. bacteriovorus strain 109J, prepared in PBS as described above, were applied in $50 \mu \mathrm{L}$ samples to the surfaces of ex vivo porcine corneas and contact lenses (CL) were applied. PBS alone was used as a negative control, and S. marcescens strain K904 in PBS $\left(3 \times 10^{9}\right)$ was applied as a control pathogen. Porcine eyes were obtained from Sierra Medical (Whittier, CA, USA) and corneal organ culture was performed as previously described but without antibiotics [52,53]. The ex vivo corneas were incubated at $37^{\circ} \mathrm{C}$ for $3 \mathrm{~h}$, then the CL were removed. The corneas were rinsed twice with PBS to remove non- or loosely adherent bacteria and fixed with glutaraldehyde (3\%) overnight at room temperature. Corneas were then washed with PBS and post-fixed using aqueous osmium tetroxide (1\%), dehydrated using increasing ethanol concentrations (30-100\%), immersed in hexamethyldisilazane, air dried, and sputter coated with gold/palladium $(6 \mathrm{~nm})$. A 
JEOL JSM-6335F scanning electron microscope at $3 \mathrm{kV}$ with the secondary electron imaging detector was used for imaging.

\subsection{In Vitro Predation Assay}

Susceptibility of S. marcescens strain K904 to B. bacteriovorus strain HD100 was tested as previously described [30]. HD100 and K904 were combined in $14 \mathrm{~mL}^{2}$ Falcon ${ }^{\mathrm{TM}}$ roundbottom polypropylene tubes by adding $0.4 \mathrm{~mL}$ of harvested predators $\left(5 \times 10^{8} \mathrm{PFU} / \mathrm{mL}\right)$ to 0.4 washed S. marcescens $\left(4 \times 10^{9} \mathrm{CFU} / \mathrm{mL}\right.$ ) and $1.2 \mathrm{~mL}$ HEPES buffer (HEPES at $25 \mathrm{mM}$ supplemented with $\mathrm{CaCl}_{2}$ at $2 \mathrm{mM}$ and $\mathrm{MgCl}_{2}$ at $3 \mathrm{mM}$ ). These were incubated at $30^{\circ} \mathrm{C}$ on a rotary shaker set at $30 \mathrm{rpm}$. A control without $B$. bacteriovorus was included as a control. Colony forming units of $S$. marcescens were determined by dilution plating on LB agar plates after 24 of coculture. The experiment was repeated three times.

\subsection{Rabbit Ocular Surface Occupancy Model}

This study conformed to the ARVO Statement on the Use of Animals in Ophthalmic and Vision Research and was approved by the University of Pittsburgh Institutional Animal Care and Use Committee (Protocol 15025331). Female New Zealand white rabbits weighing 1.1-1.4 kg, were obtained from Charles River Oakwood rabbitry.

For the inocula, P. aeruginosa strain PAC and S. marcescens strain K904 were swabbed onto 5 blood agar plates and incubated at $37^{\circ} \mathrm{C}$ overnight. Bacteria were scraped off the plates using a cotton tipped applicator and suspended in $5 \mathrm{~mL}$ of phosphate buffered saline (PBS) and adjusted to a culture density of $\mathrm{OD}_{600}$ of 5 in PBS. P. aeruginosa and S. marcescens inocula colony counts were determined using the EddyJet 2 spiral plating system (Neutec Group Inc., Farmingdale, NY, USA) on blood agar plates. The plates were incubated overnight at $37^{\circ} \mathrm{C}$ for $P$. aeruginos $a$ and $30^{\circ} \mathrm{C}$ for $S$. marcescens and resulting colonies were enumerated using the automated Flash and Grow colony counting system (Neutec Group), with $\left(\sim 5 \times 10^{8} \mathrm{CFU}\right)$ in $50 \mu \mathrm{L}$ samples of bacteria that were applied to the ocular surface of both eyes of unanesthetized rabbits. Fifty $\mu \mathrm{L}$ of the predatory bacteria were installed into the rabbits' eyes and consisted of $2 \times 10^{8} \mathrm{PFU} / \mathrm{mL}$ for B. bacteriovorus and $2 \times 10^{7} \mathrm{PFU} / \mathrm{mL}$ for M. aeruginosavorus.

The ocular surfaces of both rabbit eyes were inoculated with P. aeruginosa $(n=12$ rabbits) and S. marcescens ( $n=8$ rabbits). At $0.5,2,4$, and 24 post-inoculation, each eye was cultured following topical anesthesia with 2 drops of $0.5 \%$ proparacaine (Proparacaine Hydrochloride Ophthalmic Solution, USP, 0.5\%, Sandoz Inc., Princeton, NJ, USA) by inserting a Dacron-tipped applicator into the upper and lower fornices and gently manipulating the swab over the conjunctival and corneal surfaces. Swabs were placed into $1 \mathrm{~mL}$ of PBS and kept on ice. Dilutions (1:100 and 1:10,000) of the samples were made in PBS. The undiluted and diluted samples were plated on blood agar plates to enumerate bacteria as describe above. At 1,3 , and $5 \mathrm{~h}$ post-inoculation, $50 \mu \mathrm{L}$ topical drops with predatory bacteria or saline were applied to eyes. P. aeruginosa and S. marcescens remaining of the ocular surface were enumerated as described above. Median colony forming units (CFU) were compared using non-parametric analysis with GraphPad Prism software.

\subsection{Statistical Analysis}

Mann-Whitney analysis was performed using GraphPad Prism statistical software version 6.0. $p$-values less than 0.05 were considered significant.

Author Contributions: E.G.R. contributed to the research design; E.G.R. obtained Institutional Animal Care and Use Committee approval and upheld regulations; E.G.R. directed rabbit experiments; and E.G.R. coauthored and reviewed the final manuscript. S.G. contributed to the research design; S.G. directed preparation of predatory bacteria; S.G. determined predatory bacteria numbers; and S.G. reviewed the final manuscript. A.P. prepared predatory bacteria; A.P. determined predatory bacteria numbers, and the review and writing of the final manuscript. D.E.K. contributed to the research design; D.E.K. participated in the writing and review of the final manuscript. R.M.Q.S. contributed to the research design; R.M.Q.S. prepared bacterial inocula; R.M.Q.S. participated in 
the writing and review of the final manuscript. All authors have read and agreed to the published version of the manuscript.

Funding: The Ophthalmology Department has received support from: NIH grants P30-EY08098, the Eye and Ear Foundation of Pittsburgh, Research to Prevent Blindness. This work was funded by the U.S. Army Research Office and the Defense Advanced Research Projects Agency (DARPA) and was accomplished under Cooperative Agreement Number W911NF-15-2-0036 to D.E.K. and R.M.Q.S. The views and conclusions contained in this document are those of the authors and should not be interpreted as representing the official policies, either expressed or implied, of the Army Research Office, DARPA, or the U.S. Government. The U.S. Government is authorized to reproduce and distribute reprints for Government purposes notwithstanding any copyright notation hereon.

Institutional Review Board Statement: Animal studies conformed to the Association for Research in Vision and Ophthalmology Statement on the Use of Animals in Ophthalmic and Vision Research, and was approved by the University of Pittsburgh Institutional Animal Care and Use Committee (Protocol 15025331).

Informed Consent Statement: Not applicable.

Data Availability Statement: Data are available on request.

Acknowledgments: The authors thank Kimberly Brothers, Nicholas Stella, and Kathleen Yates for expert technical help and Jonathan Franks at the Center for Biological Imaging at the University of Pittsburgh for SEM analysis.

Conflicts of Interest: The authors declare no conflict of interest.

\section{References}

1. Dwidar, M.; Monnappa, A.K.; Mitchell, R.J. The dual probiotic and antibiotic nature of Bdellovibrio bacteriovorus. BMB Rep. 2012, 45, 71-78. [CrossRef]

2. Sockett, R.E. Predatory lifestyle of Bdellovibrio bacteriovorus. Annu. Rev. Microbiol. 2009, 63, 523-539. [CrossRef]

3. Kadouri, D.E.; To, K.; Shanks, R.M.; Doi, Y. Predatory bacteria: A potential ally against multidrug-resistant Gram-negative pathogens. PLoS ONE 2013, 8, e63397. [CrossRef]

4. Shanks, R.M.; Davra, V.R.; Romanowski, E.G.; Brothers, K.M.; Stella, N.A.; Godboley, D.; Kadouri, D.E. An Eye to a Kill: Using Predatory Bacteria to Control Gram-Negative Pathogens Associated with Ocular Infections. PLoS ONE 2013, 8, e66723. [CrossRef]

5. Pasternak, Z.; Njagi, M.; Shani, Y.; Chanyi, R.; Rotem, O.; Lurie-Weinberger, M.N.; Koval, S.; Pietrokovski, S.; Gophna, U.; Jurkevitch, E. In and out: An analysis of epibiotic vs periplasmic bacterial predators. ISME J. 2014, 8, 625-635. [CrossRef]

6. Kadouri, D.; O'Toole, G.A. Susceptibility of biofilms to Bdellovibrio bacteriovorus attack. Appl. Environ. Microbiol. 2005, 71, 4044-4051. [CrossRef] [PubMed]

7. Kadouri, D.; Venzon, N.C.; O’Toole, G.A. Vulnerability of pathogenic biofilms to Micavibrio aeruginosavorus. Appl. Environ. Microbiol. 2007, 73, 605-614. [CrossRef]

8. Dharani, S.; Kim, D.H.; Shanks, R.M.Q.; Doi, Y.; Kadouri, D.E. Susceptibility of colistin-resistant pathogens to predatory bacteria. Res. Microbiol. 2018, 169, 52-55. [CrossRef] [PubMed]

9. Duncan, M.C.; Gillette, R.K.; Maglasang, M.A.; Corn, E.A.; Tai, A.K.; Lazinski, D.W.; Shanks, R.M.Q.; Kadouri, D.E.; Camilli, A. High-throughput analysis of gene function in the bacterial predator Bdellovibrio bacteriovorus. mBio 2019, 10, e01040-19. [CrossRef]

10. Romanowski, E.G.; Stella, N.A.; Brothers, K.M.; Yates, K.A.; Funderburgh, M.L.; Funderburgh, J.L.; Gupta, S.; Dharani, S.; Kadouri, D.E.; Shanks, R.M. Predatory bacteria are nontoxic to the rabbit ocular surface. Sci. Rep. 2016, 6, 30987. [CrossRef]

11. Nakamura, M. Alteration of Shigella pathogenicity by other bacteria. Am. J. Clin. Nutr. 1972, 25, 1441-1451. [CrossRef]

12. Boileau, M.J.; Mani, R.; Breshears, M.A.; Gilmour, M.; Taylor, J.D.; Clickenbeard, K.D. Efficacy of Bdellovibrio bacteriovorus 109J for the treatment of dairy calves with experimentally induced infectious bovine keratoconjunctivitis. Am. J. Vet. Res. 2016, 77, 1017-1028. [CrossRef]

13. Shatzkes, K.; Chae, R.; Tang, C.; Ramirez, G.C.; Mukherjee, S.; Tsenova, L.; Connell, N.D.; Kadouri, D.E. Examining the safety of respiratory and intravenous inoculation of Bdellovibrio bacteriovorus and Micavibrio aeruginosavorus in a mouse model. Sci. Rep. 2015, 5, 12899. [CrossRef] [PubMed]

14. Gupta, S.; Tang, C.; Tran, M.; Kadouri, D.E. Effect of predatory bacterio on human cell lines. PLoS ONE 2016, 11, e0161242. [CrossRef]

15. Monnappa, A.K.; Bari, W.; Choi, S.Y.; Mitchell, R.J. Investigating the responses of human epithelial cells to predatory bacteria. Sci. Rep. 2016, 15, 33485. [CrossRef]

16. Shatzkes, K.; Singleton, E.; Tang, C.; Zuena, M.; Shukla, S.; Gupta, S.; Dharani, S.; Onyile, O.; Rinaggio, J.; Connell, N.D.; et al. Predatory bacteria attenuate Klebsiella pneumoniae burden in rat lungs. mBio 2016, 7, e01847-16. [CrossRef]

17. Findlay, J.S.; Flick-Smith, H.C.; Keyser, E.; Cooper, I.A.; Williamson, E.D.; Oyston, P.C.F. Predatory bacteria can protectx SKH-1 mice from a lethal plague challenge. Sci. Rep. 2019, 9, 7225. [CrossRef] 
18. Willis, R.A.; Moore, C.; Mazon-Moya, M.; Krokowski, S.; Lambert, C.; Till, R.; Mostowy, S.; Sockett, R.E. Injections of predatory bacteria work alongside host immune cells to treat Shigella infections in zebrafish larvae. Curr. Biol. 2016, 26, 3343-3351. [CrossRef] [PubMed]

19. Das, S.; Sheorey, H.; Taylor, H.R.; Vajpayee, R.B. Association between cultures of contact lens and corneal scraping in contact lens related microbial keratitis. Arch. Ophthalmol. 2007, 125, 1182-1185. [CrossRef]

20. Green, M.; Sara, S.; Hughes, I.; Apel, A.; Stapleton, F. Trends in contact lens microbial keratitis 1999 to 2015: A retrospective clinical review. Clin. Exp. Ophthalmol. 2019, 47, 726-732. [CrossRef]

21. Mah-Sadorra, J.H.; Najjar, D.M.; Rapuano, C.J.; Laibson, P.R.; Cohen, E.J. Serratia corneal ulcers: A retrospective clinical study. Cornea 2005, 24, 793-800. [CrossRef]

22. Lakhundi, S.; Siddiqui, R.; Khan, N.A. Pathogenesis of microbial keratitis. Microb. Pathog. 2017, 104, 97-109. [CrossRef]

23. Hume, E.B.; Willcox, M.D. Emergence of Serratia marcescens as an ocular surface pathogen. Arch. Soc. Esp. Oftalmol. 2004, 79, 475-477.

24. Hilliam, Y.; Kaye, S.; Winstanley, C. Pseudomonas aeruginosa and microbial keratitis. J. Med. Microbiol. 2020, 69, 3-13. [CrossRef] [PubMed]

25. Green, M.; Apel, A.; Stapleton, F. Risk factors and causative organisms in microbial keratitis. Cornea 2008, 27, 22-27. [CrossRef] [PubMed]

26. Willcox, M.D. Review of resistance of ocular isolates of Pseudomonas aeruginosa and staphylococci from keratitis to ciprofloxacin, gentamicin and cephalosporins. Clin. Exp. Optom. 2011, 94, 161-168. [CrossRef]

27. Shen, E.P.; Hsieh, Y.T.; Chu, H.S.; Chang, S.C.; Hu, F.R. Correlation of Pseudomonas aeruginosa genotype with antibiotic susceptibility and clinical features of induced central keratitis. Investig. Ophthalmol. Vis. Sci. 2014, 56, 365-371. [CrossRef] [PubMed]

28. Vazirani, J.; Wurity, S.; Ali, M.H. Multidrug-Resistant Pseudomonas aeruginosa Keratitis: Risk Factors, Clinical Characteristics, and Outcomes. Ophthalmology 2015, 122, 2110-2114. [CrossRef]

29. Fernandes, M.; Vira, D.; Medikonda, R.; Kumar, N. Extensively and pan-drug resistant Pseudomonas aeruginosa keratitis: Clinical features, risk factors, and outcome. Graefes Arch. Clin. Exp. Ophthalmol. 2016, 254, 315-322. [CrossRef]

30. Garcia, C.J.; Pericleous, A.; Elsayed, M.; Tran, M.; Gupta, S.; Callaghan, J.D.; Stella, N.A.; Franks, J.M.; Thibodeau, P.H.; Shanks, R.M.Q.; et al. Serralysin family metalloproteases protects Serratia marcescens from predation by the predatory bacteria Micavibrio aeruginosavorus. Sci. Rep. 2018, 8, 14025. [CrossRef]

31. Shanks, R.M.; Stella, N.A.; Hunt, K.M.; Brothers, K.M.; Zhang, L.; Thibodeau, P.H. Identification of SlpB, a cytotoxic protease from Serratia marcescens. Infect. Immun. 2015, 83, 2907-2916. [CrossRef]

32. Stella, N.A.; Callaghan, J.D.; Zhang, L.; Brothers, K.M.; Kowalski, R.P.; Huang, J.J.; Thibodeau, P.H.; Shanks, R.M.Q. SlpE is a calcium-dependent cytotoxic metalloprotease associated with clinical isolates of Serratia marcescens. Res. Microbiol. 2017, 168, 567-574. [CrossRef] [PubMed]

33. Stella, N.A.; Brothers, K.M.; Shanks, R.M.Q. Differential susceptibility of airway and ocular surface cell lines to FlhDC-mediated virulence factors PhlA and ShlA from Serratia marcescens. J. Med. Microbiol. 2021, 70, 001292. [CrossRef]

34. Atterbury, R.J.; Hobley, L.; Till, R.; Lambert, C.; Capeness, M.J.; Lerner, T.R.; Fenton, A.K.; Barrow, P.; Sockett, R.E. Effects of orally administered Bdellovibrio bacteriovorus on the well-being and Salmonella colonization of young chicks. Appl. Environ. Microbiol. 2011, 77, 5794-5803. [CrossRef]

35. Doan, T.; Akileswaran, L.; Andersen, D.; Johnson, B.; Ko, N.; Shrestha, A.; Shestopalov, V.; Lee, C.S.; Lee, A.Y.; Van Gelder, R.D. Paucibacterial microbiome and resident DNA virome of the healthy conjunctiva. Investig. Ophthalmol. Vis. Sci. 2016, 57, 5116-5126. [CrossRef]

36. Ozkan, J.; Willcox, M.D. The ocular microbiome: Molecular characterization of a unique and low microbial environment. Curr. Eye Res. 2019, 44, 685-694. [CrossRef] [PubMed]

37. Petrillo, F.; Pignataro, D.; Lavano, M.A.; Santella, B.; Folliero, V.; Zannella, C.; Astarita, C.; Gagliano, C.; Franci, G.; Avitabile, T.; et al. Current evidence on the ocular surface microbiota and related diseases. Microorganisms 2020, 8, 1033. [CrossRef]

38. Shatzkes, K.; Tang, C.; Singleton, E.; Shukla, S.; Zuena, M.; Gupta, S.; Dharani, S.; Rinaggio, J.; Connell, N.D.; Kadouri, D.E. Effect of predatory bacteria on the gut bacterial microbiota in rats. Sci. Rep. 2017, 7, 43483. [CrossRef]

39. Lebba, V.; Santangelo, F.; Totino, V.; Nicoletti, M.; Gagliardi, A.; De Biase, R.V.; Cucchiara, S.; Nencioni, L.; Conte, M.P.; Schippa, S. Higher prevalence and abundance of Bdellovibrio bacteriovorus in the human gut of healthy subjects. PLoS ONE 2013, 8, e61608. [CrossRef]

40. Dantas, P.E.; Uesugui, E.; Nishiwaki-Dantas, M.C.; Mimica, L.J. Antibacterial activity of anaesthetic solutions and preservatives: An in vitro comparative study. Cornea 2000, 19, 353-354. [CrossRef]

41. Edwards, S.G.; Maggs, D.J.; Byrne, B.A.; Kass, P.H.; Lassaline, M.E. Effect of topical application of 0.5\% proparacaine on corneal culture results from 33 dogs, 12 cats, and 19 horses with spontaneously arising ulcerative keratitis. Vet. Ophthalmol. 2019, 22, 415-422. [CrossRef]

42. Mun, J.J.; Tam, C.; Kowbel, D.; Hawgood, S.; Barnett, M.J.; Evans, D.J.; Fleiszig, S.M. Clearance of Pseudomonas aeruginosa from a healthy ocular surface involves surfactant protein $\mathrm{D}$ and is compromised by bacterial elastase in a murine null-infection model. Infect. Immun. 2009, 77, 2392-2398. [CrossRef] 
43. St Leger, A.J.; Desai, J.V.; Drummond, R.A.; Kugadas, A.; Almaghrabi, F.; Silver, P.; Raychaudhuri, K.; Gadjeva, M.; Iwakura, Y.; Lionakis, M.S.; et al. An ocular commensal protects against corneal infection by driving an interleukin-17 response from mucosal $\gamma \delta$ T cells. Immunity 2017, 47, 148-158. [CrossRef]

44. Kowalski, R.P.; Pandya, A.N.; Karenchak, L.M.; Romanowski, E.G.; Husted, R.C.; Ritterband, D.C.; Shah, M.K.; Gordon, Y.J. An in vitro resistance study of levofloxacin, ciprofloxacin, and ofloxacin using keratitis isolates of Staphylococcus aureus and Pseudomonas aeruginosa. Ophthalmology 2001, 108, 1826-1829. [CrossRef]

45. Kalivoda, E.J.; Stella, N.A.; Aston, M.A.; Fender, J.E.; Thompson, P.P.; Kowalski, R.P.; Shanks, R.M. Cyclic AMP negatively regulates prodigiosin production by Serratia marcescens. Res. Microbiol. 2010, 161, 158-167. [CrossRef]

46. Cockerill, F.R. Performance Standards for Antimicrobial Susceptibility Testing; Twenty-Third Informational Supplement; CLSI: Wayne, PA, USA, 2013.

47. Kowalski, R.P.; Dhaliwal, D.K.; Karenchak, L.M.; Romanowski, E.G.; Mah, F.S.; Ritterband, D.C.; Gordon, Y.J. Gatifloxacin and moxifloxacin: An in vitro susceptibility comparison to levofloxacin, ciprofloxacin, and ofloxacin using bacterial keratitis isolates. Am. J. Ophthalmol. 2003, 136, 500-505. [CrossRef]

48. Bertani, G. Studies on lysogenesis. I. The mode of phage liberation by lysogenic Escherichia coli. J. Bacteriol. 1951, 62, 293-300. [CrossRef] [PubMed]

49. Rittenberger, S.C. Nonidentity of Bdellovibrio bacteriovorus strains 109D and 109J. J. Bacteriol. 1972, 109, 432-433. [CrossRef] [PubMed]

50. Stolp, H.; Starr, M.P. Bdellovibrio bacteriovorus Gen. Et Sp. N., A predatory, ectoparasitic, and bacteriolytic microorganism. Antonie Van Leeuwenhoek 1963, 29, 217-248. [CrossRef]

51. Lambina, V.A.; Afinogenova, A.V.; Romay Penobad, Z.; Konovalova, S.M.; Andreev, L.V. New species of exoparasitic bacteria of the genus Micavibrio infecting gram-negative bacteria. Mikrobiologiia 1983, 52, 777-780.

52. Brothers, K.M.; Stella, N.A.; Hunt, K.M.; Romanowski, E.G.; Liu, X.; Klarlund, J.K.; Shanks, R.M. Putting on the brakes: Bacterial impediment of wound healing. Sci. Rep. 2015, 5, 14003. [CrossRef]

53. Xu, K.P.; Li, X.F.; Yu, F.S. Corneal organ culture model for assessing epithelial responses to surfactants. Toxicol. Sci. 2000, 58, 306-314. [CrossRef] 